\title{
肺癌の気管支鏡所見の検討
}

\section{Bronchoscopic Findings of Primary Lung Cancer}

平島智徳・木村孝文* ·平田奈穂美** ・西村純子**

松本武敏**・福田浩一郎**・田中不二穂**・岳中耐夫**・志摩 清**

要旨：原発性肺癌143例：腺癌66例, 扁平上皮癌49例, 小細胞癌28例について気管支鏡所見によ り組織型の鑑別が可能か検討した。その結果，組織鑑別には色調，血管怒張，軟骨輪消 失，閉塞が有力であり，扁平上皮癌は蒼白と閉塞所見が，腺癌は発赤所見が，小細胞癌 は血管怒張と軟骨輪消失, 発赤蒼白混合所見など多彩な所見を呈する傾向が認められた。 しかし各組織型で気管支鏡所見がオーバーラップする部分も多かった.

〔肺癌 $31(4) ： 467 \sim 472 ， 1991$ )

Key words : Primary lung cancer, Bronchoscopic findings, Histologic type.

\section{目的}

気管支ファイバースコープは呼吸器疾患, 特 に肺癌の診療上，有用な検査として定着してき た、肺癌の気管支鏡所見は各組織型によってあ る程度の特異性があることは指摘されている。 特に中枢部に好発する扁平上皮癌の気管支鏡所 見の解析は各種文献に示されている通り，進歩 してきている.しかし気管支粘膜下(気管支壁 内十上皮下) への肺癌の浸潤に関する気管支鏡 所見の解析はまだ十分なされているとは言い難 い.今回気管支鏡所見を基に肺癌の組織型の鑑 別が可能か検討した.

\section{対 象}

対象は，1985年 6 月から1990年 2 月まで熊本 市民病院と熊本大学第一内科を受診した原発性 肺癌143例 (Table 1). 男性101例, 女性42例であ る. 年齢は $31 \sim 87$ (平均 67.3 才), 組織型の内 訳は, 腺癌66例, 扁平上皮癌49例, 小細胞癌 28

\footnotetext{
現 東野病院

* 現 秋津レークタウンクリニック

** 熊本市民病院呼吸器科
}

例である.なお大細胞癌は症例数が 5 例と少な いので，今回は検討に加えなかった。病期は， 0 期 1 例， I 期 24 例 II 期 3 例， III 期 51例， IV 期 64例だった. Performance Status(PS)は, PS $0: 25$ 例, PS $1: 74$ 例, PS $2: 23$ 例, PS $3: 17$

Table 1. Characteristics of patients with primary lung cancer.

\begin{tabular}{lllrcc}
\hline & & Ad & Sq & Sm & Total \\
\hline \multirow{2}{*}{ Sex } & male & 39 & 42 & 20 & 101 \\
& female & $27^{* *}$ & 7 & 8 & 42
\end{tabular}

Age

$65.8 \pm 12.0 \quad 68.5 \pm 9.2 \quad 65.8 \pm 8.9 \quad 67.3 \pm 10.6$

\begin{tabular}{rrrrrr} 
Stage & 0 & 0 & 1 & 0 & 1 \\
& I & 12 & 11 & 1 & 24 \\
& II & 1 & 2 & 0 & 3 \\
& III & 18 & 22 & 11 & 51 \\
& IV & 35 & 13 & 16 & 64 \\
PS & 0 & 14 & 7 & 4 & 25 \\
& 1 & 33 & 27 & 14 & 74 \\
& 2 & 12 & 5 & 6 & 23 \\
& 3 & 6 & 8 & 3 & 17 \\
& 4 & 1 & 2 & 1 & 4 \\
\hline & & & & & $* * 0<0.01$
\end{tabular}


例, PS 4：4例である.検討した背景因子に関し ては, 腺癌が他の組織型に比して女性が多い $(\mathrm{p}<0.01)$ 以外特に各組織型間に有意差はなか った.

\section{方 法}

1985 1990年の 6 年間の原発性肺癌の気管支 鏡フィルム所見記録をもとに気管支鏡有経験者 3 名で再検討し，判定可能なフィルムを検討し て肺癌が可視(有所見)か不可視(無所見)かを判 定し，更に可視例を詳細に検討した。なお機種 としてはオリンパス製のフレキシブルブロンコ スコピー(type10，type20，1T10，1T20)を用い た. 検討の方法としては肺癌取り扱い規約 ${ }^{1} に$ 沿って可視例を粘膜主体型と粘膜下主体型にわ けて粘膜主体型は表層浸潤型，結節型，ポリー プ型に，粘膜下主体型は，上皮下型，壁内型に 分けた。なお壁外所見は所見より除外した。次 に腫瘍部の所見として色調 (蒼白, 蒼白発赤, 発 赤), 光沢消失 (有, 無), 腫張 (有, 無), 血管怒 張 (有, 無), 顆粒状変化 (有, 無), 縦走譬 (消 失，正常，増高消失混在，増高)，軟骨輪消失 (有, 無), 狭窄 (有, 無), 閉塞 (有, 無)の 10 項 目をそれぞれ検討した (Table 2)なお有意差検 定の方法として，出現率には $\chi$ 二乗検定を用い 有意差検定は $\mathrm{p}<0.05$ を推計学的に有意差あり とした。今回ひとつの試みとして上記10項目を 用いて多変量解析の判別分析法 ${ }^{2)}$ で腺癌, 扁平 上皮癌, 小細胞癌の判別がどの程度可能か検討 した.

\section{結 果}

\section{I。有所見率}

有所見率は腺癌が66例中 26 例 $(39.4 \%)$ ，扁平 上皮癌が 49 例中 39 例 $(79.6 \%)$, 小細胞癌が 28 例 中 25 例 $(89.3 \%)$ と腺癌は有意に有所見率が低か った (Table 3$).(\mathrm{p}<0.01)$

\section{2. 各組織型における粘膜主体型と粘膜下主体} 型

腺癌は粘膜主体型 (M) 6 例 (23.1\%)，粘膜下 主体型 (SM) 20 例 (76.9\%)。扁平上皮癌は M : 32 例 (82.1\%), SM： 7 例 (17.9\%) 小細胞癌は
Table 2. 10 parameters of bronchoscopic findings.

\begin{tabular}{|c|c|c|c|c|}
\hline & & $\mathrm{Ad}$ & $\mathrm{Sq}$ & $\mathrm{Sm}$ \\
\hline \multicolumn{5}{|l|}{ 1. color } \\
\hline \multicolumn{2}{|c|}{ normal } & 1 & 2 & 0 \\
\hline \multicolumn{2}{|c|}{ paleness } & 4 & 19 & 2 \\
\hline \multicolumn{2}{|c|}{ mixed redness and paleness } & 1 & 9 & 12 \\
\hline \multicolumn{2}{|c|}{ redness } & 20 & 9 & 11 \\
\hline \multirow[t]{2}{*}{ 2. loss of luster } & + & 17 & 29 & 17 \\
\hline & - & 9 & 10 & 8 \\
\hline \multirow[t]{2}{*}{ 3. swelling } & + & 18 & 20 & 22 \\
\hline & - & 8 & 19 & 3 \\
\hline \multirow[t]{2}{*}{ 4. vascular engorgement } & + & 11 & 14 & 17 \\
\hline & - & 15 & 25 & 8 \\
\hline \multirow[t]{2}{*}{ 5. granular change } & + & 9 & 19 & 11 \\
\hline & - & 17 & 20 & 14 \\
\hline \multicolumn{5}{|l|}{ 6. longitudinal folds } \\
\hline \multicolumn{2}{|c|}{ opaque } & 12 & 7 & 6 \\
\hline \multicolumn{2}{|c|}{ normal } & 7 & 17 & 4 \\
\hline \multicolumn{2}{|c|}{ opaque and accentuated } & 0 & 4 & 1 \\
\hline \multicolumn{2}{|c|}{ accentuated } & 7 & 11 & 14 \\
\hline \multirow[t]{2}{*}{ 7. loss of cartilage rings } & + & 12 & 14 & 18 \\
\hline & - & 14 & 25 & 7 \\
\hline \multirow[t]{2}{*}{ 8. stenosis } & + & 17 & 24 & 23 \\
\hline & - & 9 & 15 & 2 \\
\hline \multirow[t]{2}{*}{ 9. obstruction } & + & 9 & 27 & 12 \\
\hline & - & 17 & 12 & 13 \\
\hline \multirow[t]{2}{*}{ 10. necrosis } & + & 12 & 29 & 10 \\
\hline & - & 14 & 10 & 9 \\
\hline
\end{tabular}

M：4 例 (16\%), SM：21例 (84\%)だった。扁平 上皮癌は他の組織型に比して有意に Mが多かっ た (Table 3). $(\mathrm{p}<0.01)$

\section{3.各組織型におけるSubtype}

腺癌： $\mathrm{M}$ (表層浸潤 1 例, 結節 5 例), $\mathrm{SM}$ (上 皮下 9 例, 壁内 11 例)。扁平上皮癌：M(表層浸 潤 4 例, 結節 9 例, ポリープ19例), SM(上皮下 4 例, 壁内 3 例). 小細胞癌：M(表層浸潤 0 例, 結節 1 例, ポリープ 3 例), $\mathrm{SM}$ (上皮下 13 例, 壁 内 8 例) で腺癌は壁内型が小細胞癌は上皮下型 が多かったが特に有意差を認めなかった( Table 3 ).

4.各組織型における気管支鏡所見

1) 色調：腺癌は発赤が26例中 20 例 (76.9\%) で扁 平上皮癌 $(\mathrm{p}<0.01)$, 小細胞癌 $(\mathrm{p}<0.05)$ に比し 
Table 3. Bronchoscopic findings of lung cancer recognized by Japan Cancer Society in 1987.

\begin{tabular}{lllll}
\hline & Ad & Sq & Sm & Total \\
\hline visible & $26(39.4 \%)^{* *}$ & $39(79.6 \%)$ & $25(89.3 \%)$ & $90(63.0 \%)$ \\
invisible & 40 & 10 & 3 & 53 \\
\hline \multicolumn{1}{c}{ total } & 66 & 49 & 28 & 143 \\
\hline primarily mucosal type & $6(23.1 \%)$ & $32(82.1 \%)^{* *}$ & $4(16 \%)$ & $42(46.7 \%)$ \\
\hline 1. superficial infiltrating & 1 & 4 & 0 & 5 \\
2. nodular infiltrating & 5 & 9 & 1 & 15 \\
3. polypoid & 0 & 19 & 3 & 22 \\
\hline primarily submucosal type & $20(76.9 \%)$ & $7(17.9 \%)$ & $21(84 \%)$ & $48(53.3 \%)$ \\
\hline 1. subepithelial & 9 & 4 & 13 & 26 \\
2. intramural & 11 & 3 & 8 & 22 \\
\hline
\end{tabular}

て有意に多かった。扁平上皮癌 は蒼白が39例中19例 (48.7\%) で 腺癌，小細胞癌に比して有意に 多かった $(\mathrm{p}<0.01)$ ．小細胞癌 は発赤蒼白混合が 25 例中 12 例 $(48 \%)$ で腺癌 $(\mathrm{p}<0.01)$, 扁平 上皮癌 $(\mathrm{p}<0.05)$ に比して有意 に多かった(Table 4).

2)血管怒張：小細胞癌で25例中 17 例 $(68 \%)$ と多く，特に扁平上 皮癌に比して有意に多かった (Table 5). $(\mathrm{p}<0.01)$

3) 軟骨輪消失：小細胞癌で 25 例 中18例 $(72 \%)$ と多く，特に扁平 上皮癌に比して有意に多かった

(Table 5). ( $\mathrm{p}<0.01)$

4) 閉塞 : 扁平上皮癌で39例中 27 例 (69.2\%) と多 く, 特に腺癌に対しては有意に多かった (Table 5). $(\mathrm{p}<0.01)$

光沢消失, 腫張, 顆粒状変化, 縦走壁, 狭窄 壊死に関し，特に有意差はなかった。

以上の結果より各組織型での典型的な気管支 鏡所見として，腺癌は有所見率が低く，粘膜下 主体型の壁内型を呈し発赤が強い，そして扁平 上皮癌は有所見率が高く粘膜主体型のポリープ 型を呈し蒼白調で閉塞を伴うことが多く，また 小細胞癌は有所見率が高く, 粘膜下主体型で上
Table 4. Bronchoscopic findings-1.

\begin{tabular}{|c|c|c|c|c|c|}
\hline & normal $(\%)$ & paleness $(\%)$ & $\begin{array}{l}\text { mixed redness } \\
\text { and paleness }(\%)\end{array}$ & \multicolumn{2}{|c|}{ redness $(\%)$} \\
\hline Ad & $1(3.8)$ & $4(15.4) \square *$ & $1(3.8)$ & $20(76.9)$ & \\
\hline $\mathrm{Sq}$ & $2(5.1)$ & $19(48.7) \beth_{*}^{*}$ & $9(23.1) \square$ * & $9(23.1) \sqcup *$ & * \\
\hline $\mathrm{Sm}$ & $0(0)$ & $2(8) \square *$ & $12(48)-$ & $11(44)$ & - \\
\hline
\end{tabular}

Table 5. Bronchoscopic findings -2 .

\begin{tabular}{|c|c|c|c|c|c|c|}
\hline & \multicolumn{2}{|c|}{ vascular engorgement } & \multicolumn{2}{|c|}{ loss of cartilage rings } & \multicolumn{2}{|c|}{ obstruction } \\
\hline & $+(\%)$ & - & $+(\%)$ & - & $+(\%)$ & - \\
\hline $\mathrm{Ad}$ & $11(42.3)$ & 15 & $12(46.2)$ & 14 & $9(34.6) \square *$ & 17 \\
\hline $\mathrm{Sq}$ & $14(35.9)-$ & 25 & $14(35.9)-$ & 25 & $27(69.2) \square *$ & 12 \\
\hline Sm & $17(68)$ & 8 & $18(72)$ & 7 & $12(48)$ & 13 \\
\hline
\end{tabular}

皮下型がやや多く発赤蒼白混合し血管怒張と軟 骨輪消失などその他多彩な所見を伴うことが多 いと考えられる。

5. 判別分析による組織型の鑑別

今回ひとつの試みとして，先述 10 項目により 腺癌, 扁平上皮癌, 小細胞癌の判別が可能であ るか否かを検討するため多変量解析の判別分析 を行った。な㧍多変量解析で各所見を数值化す る為に名ミ一変数を用いた。すなわち，所見の 有無を検討する場合，無を 0 ，有を 1 とした。 また色調では，正常を 0 , 蒼白を 1 , 蒼白発赤 混合を 2 , 発赤を 3 とし, 縦走璧では消失を 0 , 
正常を 1 ，増高消失混合を 2 ，増高を 3 として いる，そのようにして，各所見中 $\mathrm{F}$ 值 2.0 以上 の重要性を持ったものを变数増加法で選択した ところ, 色調 ( $\mathrm{F}$ 值9.245), 血管怒張 $(\mathrm{F}$ 值 5.261 ), 軟骨輪消失 ( F 值2.661), 閉塞 ( F 值 2.277)の順に重要であることが分かった．前述 した有意差を持った所見と一致している.

Table 6に示す判別係数をもとに, 判別関数 1 , 2 の式をもとめ各々の所見の夕゙ミ一変数を代入 し得られた判別得点をプロットした。分布図の 縦軸は主に血管怒張と軟骨輪消失所見の変化を 示し (判別関数 1 ), 横軸は主に色調と閉塞所見 の変化を示している(判別関数 2 ). 腺癌は発赤, 扁平上皮癌は閉塞十蒼白，小細胞癌は血管怒 張十軟骨輪消失の他多彩な所見を呈するグルー プに集中する傾向がみられた。しかしかなりば らつきも大きく各組織型でオーバーラップする 部分も多かった (Fig. 1).
Table 6. Discriminant function.

\begin{tabular}{lrr}
\hline & $\begin{array}{c}\text { discriminant } \\
\text { function-1 }\end{array}$ & $\begin{array}{c}\text { discriminant } \\
\text { function-2 }\end{array}$ \\
\hline color (C) & 1.058 & -0.208 \\
engorgment of vessels (E) & -0.897 & 1.543 \\
loss of cartilage ring (L) & 0.374 & 1.280 \\
obstruction (O) & -0.971 & 0.176 \\
constant & -1.518 & -0.994 \\
\hline
\end{tabular}

\footnotetext{
Discriminant function- 1

$=1.058 \mathrm{C}-0.897 \mathrm{E}+0.374 \mathrm{~L}-0.971 \mathrm{O}-1.518$

Discriminant function-2

$=-0.208 \mathrm{C}+1.543 \mathrm{E}+1.280 \mathrm{~L}+0.176 \mathrm{O}-0.994$
}

\section{考按}

肺癌のなかでも扁平上皮癌の気管支鏡所見に 関しては詳細に検討がなされているが腺癌及び 小細胞癌についてはあまりなされていなかった。 近年病期の推定や手術適応について気管支鏡所 見は, 有用との報告もある。しかし, 組織型別
Fig. 1.

Distribution of hostologic types according to discriminant score. Four parameters of bronchoscopic findings (color, vascular engorgement, loss of cartilage rings, obstruction) were analyzed by canonical discriminant analysis. Vertical axis mainly showed loss of cartilage rings and vascular engorgement. Horizontal axis mainly showed color and obstruction. Histologic types showed individual distribution according to discriminant score.

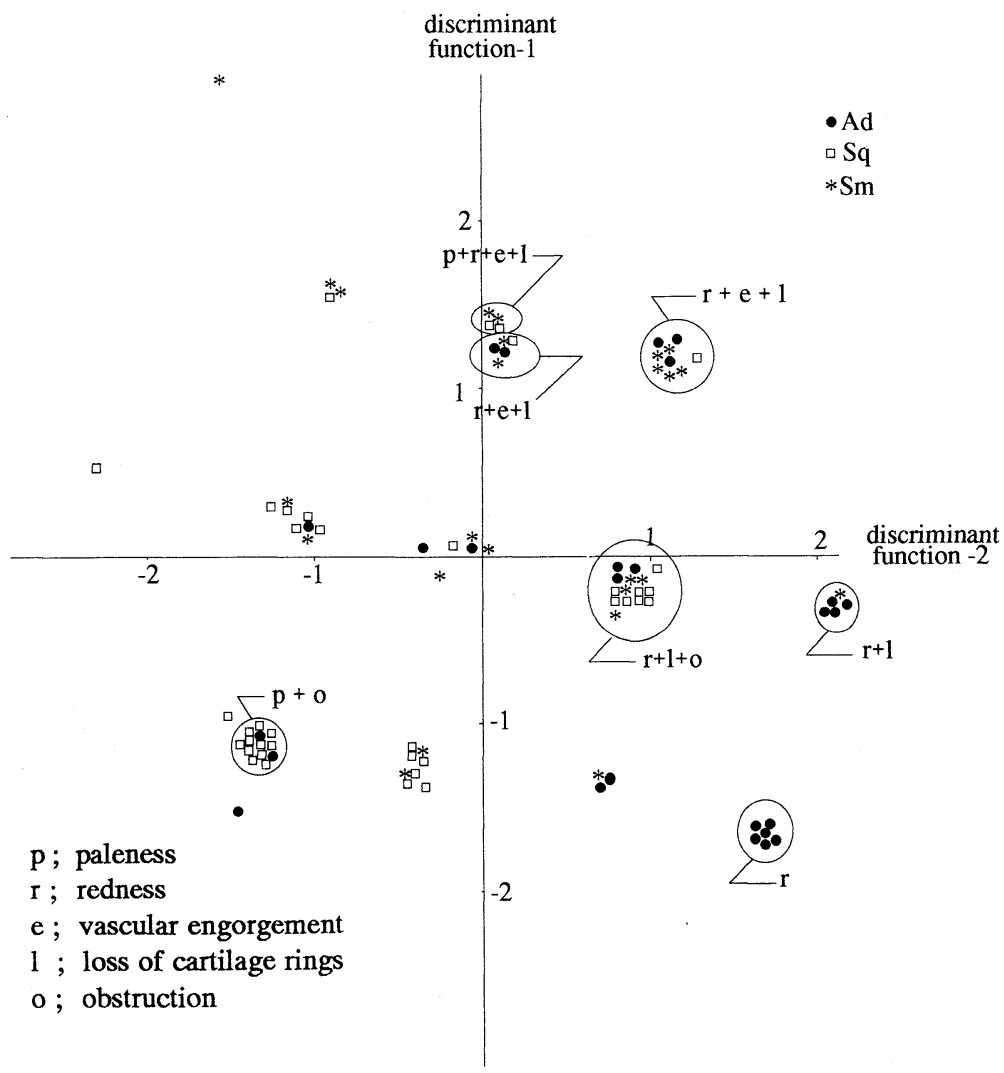


の気管支鏡所見の比較などの検討はなされてい ない。野等 ${ }^{3} の$ 報告によれば腺癌1434例中有 所見率は69\%で，その内訳はポリープ状腫瘤 47 例 (22.2\%), 結節状腫瘤は318例 (32.2\%), 閉塞 を呈したのは462例 (32.3\%)，浸潤は12例 (11.3 \%)だった。同様に小野等4)の報告で小細胞癌 417 例中, 有所見率は $93.8 \%$ で，その内訳はポリ ープ状腫瘤は52例 (12.5\%)，浸潤を呈したのは 237例 (56.8\%)，閉塞は102例 (24.5\%) だった。 また彭5)によれば末梢型腺癌 243 例中有所見率 は59.7\%で壁内浸潤型が51.7\%，粘膜上皮下浸 潤型20.0\%，壁外型14.5\%ポリープ型13.8\%で あった。東口等 ${ }^{6}$ によれば直接と間接所見を合 わせた有所見率が腺癌では 56 例 $(75 \%)$, 扁平上 皮癌では67例 (91\%)，小細胞癌では27例 (100\%) であった．東口等の述べた直接所見は，粘膜の 凹凸不整，壊死腫瘤，狭窄または閉塞で主に粘 膜主体型を示すものと思われ，間接所見は，発 赤腫張，血管怒張，軟骨輪の不明瞭化，粘膜璧 肥厚, 粘膜襞不明瞭化で主に粘膜下主体型を示 すものと思われる。これで検討した場合, 腺癌 は間接所見が有所見中 $52 \%$, 扁平上皮癌は $18 \%$, 小細胞癌は $15 \%$ で腺癌は粘膜下主体型が多く扁 平上皮癌と小細胞癌は粘膜主体型が多かったと 推測される．我々の症例はこれらの報告と比較 して腺癌の有所見率が $39.4 \%$ と低かった。しか し当院で検討した腺癌の壁内型は，26例中11例 (42.3\%) を占め上皮下型が 9 例 (34.6\%) で粘膜 下主体型の所見では同様の傾向を示したが，小 細胞癌は粘膜下主体型 (48\%) が多かった。小細 胞癌に関して小野等の報告と比較すると当院の 有所見率も同様に高く，結節またはポリープが 4 例 (16\%) で同程度で閉塞をきたしたのが25例 中12例 (48\%) とやや多かった. 各組織間で先述 10項目の所見を詳細に比較した文献は調べた範 囲内ではなかった。腺癌, 扁平上皮癌, 及び小
細胞癌を鑑別するのに色調，血管怒張，軟骨輪 消失, 閉塞の各所見が重要であることが, 出現 率の比較と判別分析の両方で示された。典型的 と思われる所見は腺癌で発赤, 扁平上皮癌で蒼 白十閉塞，小細胞癌で蒼白発赤混合十血管怒張 の他, 多彩な変化を示すようである. しかしこ の 4 所見だけで組織型を鑑別するのは，かなり 難しく，各組織型でオーバーラップするところ も多かった．特に腺癌と小細胞癌で類似した所 見を呈する場合があるが，千場ら ${ }^{7} の$ 報告した 長軸進展型を示す腺癌は粘膜の発赤腫張と内腔 の狭窄を主体とする浸潤による変化が強く小細 胞癌類似の病理学的発育進展様式を示し気管支 腺癌が多かったとしている，今回我々の検討に 気管支での広がりと分化度を加えていないが所 見的に腺癌と小細胞癌でオーバーラップする部 分がかなりあるのではないかという観点からも， 今後の検討に加之る必要がある。また同じよう に扁平上皮癌でも小細胞癌類似の気管支鏡所見 を示す場合があり今後の検討を要する.

\section{まとめ}

原発性肺癌143例について気管支鏡所見によ る組織型の鑑別が可能か検討した。腺癌, 扁平 上皮癌，小細胞癌の鑑別には，色調と血管怒張， 軟骨輪消失, 閉塞の 4 所見が有力であることが 示唆され, 腺癌は発赤と軟骨輪消失の所見が, 扁平上皮癌は蒼白と閉塞の所見が，小細胞癌は 血管怒張と軟骨輪消失を中心とした多彩な所見 を特徵としていた。

\section{謝 辞}

症例を提供して頂いた熊本大学第一内科, 安藤正幸助 教授，杉本峯晴講師，また病理学的に種々の助言を頂い た熊本市民病院病理の宮山東彦部長に深く感謝いたし ます。

\section{文 献}

1）日本肺癌学会編：気管支鏡分類, 臨床病理肺癌 取り扱い規約．金原出版，東京，1987。

2）柳井晴夫，高井廣文：多変量解析ハンドブッ
ク. 現代数学社, 京都：126-159, 1988.

3）小野良祐, 池田茂人：肺腺癌の気管支鏡所見. J. JNP. Soc. Cancrer, Ther., 24(7) : 1357- 
1363, July, 1989.

4）小野良祐, 池田茂人：肺小細胞癌の気管支鏡所 見. J. JNP. Soc. Cancer, Ther., 23 (11)：2663 -2668, Dec. 1988.

5）彭瑞鵬：肺末梢型腺癌における内視鏡所見 の臨床的意義に関する研究. 気管支, Vol. 7 No $1: 27-38,1985$.
6）東口隆一, 堅田 均, 三上理一郎, 他 : 原発性 肺癌の診断一当教室での気管支鏡使用を中心 として一. 奈医誌, $35: 271-278,1984$.

7）千場 博, 深井裕治, 稲吉 厚, 他: 小細胞癌 類似の発育様式を示す肺腺癌症例の検討. 気管 支, Supplement, 8:138，1986.

(原稿受付 1990 年11月30日／採択 1991 年 2 月 12 日)

\title{
Bronchoscopic Findings of Primary Lung Cancer
}

\author{
Tomonori Hirashima, Takafumi Kimura*, Naomi Hirata**, \\ Sumiko Nishimura**, Taketoshi Matsumoto**, Kouichirou Fukuda**, \\ Fuiiho Tanaka**, Shinobu Takenaka** and Kiyoshi Shima** \\ Tohya Hospital \\ *Akitsu Lake Town Clinic \\ **Department of Pulmonary Medicine, Kumamoto Municipal Hospital
}

The histologic types of primary lung cancer in relation to bronchoscopic findings were discussed. This study included 143 cases of the primary lung cancer : adenocarcinoma (Ad) 66 cases, squamous cell carcinoma (Sq) 49 cases, small cell carcinoma (Sm) 28 cases. The bronchoscopic findings were based on "Bronchoscopic Findings in Lung Cancer Classification” recognized by. the Japan Cancer Society in 1987. Furthermore we discussed 10 bronchoscopic findings : color, loss of luster, swelling, vascular engorgement, granular change, longitudinal folds, loss of cartilage rings, stenosis, necrosis, and obstruction. Ad was significantly less visible (39.4\%) in comparison with the other histologic types $(\mathrm{p}<0.01)$. Sq had a significantly high incidence of the primarily mucosal type $(82.1 \%)$ in comparison with Ad and $\mathrm{Sm}(\mathrm{p}<0.01)$. Ad had a significantly high incidence of "redness" (76.9\%), Sq had a significantly high incidence of "paleness" (48.7\%), and Sm had a significantly high incidence of "mixed redness and paleness" (48\%) in comparison with other histologic types $(\mathrm{p}<0.05)$. Concerning other bronchoscopic findings, Sm had a significantly high incidence of "vascular engorgement" (68\%) and "loss of cartilage rings" $(72 \%)$ in comparison with $\mathrm{Sq}(\mathrm{p}<0.01)$. Sq had a significantly high incidence of "obstruction" (69.2\%) in comparison with $\mathrm{Ad}(\mathrm{p}<0.01)$. To estimate the histologic types of primary lung cancer, the important bronchoscopic findings were color, vascular engorgement, and obstruction. 